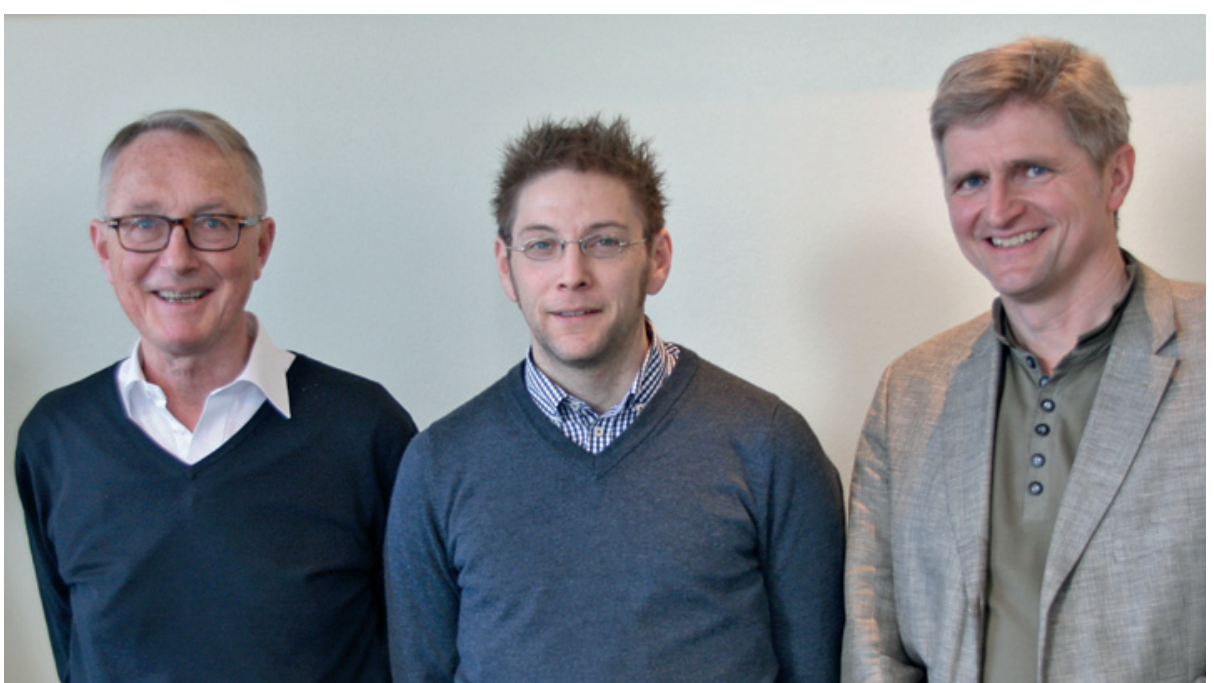

Knut Engedal, Sverre Bergh og Geir Selbæk. Foto privat

\title{
Seponering av antidepressiver ved demens
}

Selv om depressive symptomer hos pasienter med demens kan bliverre etter seponering av antidepressive legemidler, vil de fleste få ingen eller bare minimale symptomendringer. Dette viser en ny norsk studie.

$80 \%$ av pasientene på norske sykehjem har demens, og nesten alle utvikler minst ett nevropsykiatrisk symptom i tillegg. Medikamentell behandling av nevropsykiatriske symptomer er antidepressive, antipsykotiske og beroligende legemidler. Mange sykehjemspasienter får forskrevet slike medisiner.

I tidligere studier har man ikke funnet evidens for at antidepressiver har effekt ved depresjon hos pasienter med demens eller ved behandling av nevropsykiatriske symptomer ved demens. Forskerne gjennomførte derfor en randomisert studie for å undersøke effekten av å seponere slike legemidler hos sykehjemspasienter med demens.

- Studien hadde to hovedfunn, sier artikkelens førsteforfatter Sverre Bergh ved Alderspsykiatrisk forskningssenter, Sykehuset Innlandet. - For det første var snittskår på Cornells depresjonsskala etter 25 uker signifikant høyere i gruppen der antidepressivene var seponert sammenliknet med gruppen som fortsatte med antidepressiver, noe som indikerer økte depressive symptomer etter seponering. For det andre tålte de fleste pasientene at antidepressivene ble seponert. Etter 25 uker hadde kun $14 \%$ av pasientene i seponeringsgruppen skår over 13 på Cornells depresjonsskala, som er grenseverdien for en alvorlig depresjon. Disse resultatene ble bekreftet ved analyse av de affektive symptomene i nevropsykiatrisk intervjuguide. For andre nevropsykiatriske symptomer, kognisjon og livskvalitet fant vi ingen statistisk signifikant forskjeller mellom gruppene.
Ordforklaringer

Nevropsykiatriske symptomer: Demenssykdommer kjennetegnes av nedsatt hukommelse og kognitiv funksjon, men minst like fremtredende kan de nevropsykiatriske symptomene være. Nevropsykiatriske symptomer er psykologiske av natur, f.eks. depresjon, angst, hallusinasjoner og vrangforestillinger, eller endrer atferden til pasienten, f.eks. apati, aggresjon, motorisk uro, vandring og irritasjon.

Cornells depresjonsskala: Observasjonsbasert intervjuskjema for kartlegging av depresjonssymptomer. Det er utviklet for bruk hos pasienter med demens. Maksimumskår er 38 poeng, og en skår over 13 indikerer alvorlig depresjon.

Nevropsykiatrisk intervjuguide: Observasjonsbasert intervjuskjema for kartlegging av nevropsykiatriske symptomer. Skårer frekvens og intensitet for 12 forskjellige nevropsykiatriske symptomer.
Den kliniske betydningen av denne studien er at man for de fleste pasienter med demens som står på antidepressiver, trygt kan prøveseponere. Et lite mindretall blir klinisk alvorlig deprimert etter seponering og bør derfor starte opp igjen med medisineringen, sier Bergh.

\section{Forskergruppen}

Studien er initiert av og gjennomført ved Alderspsykiatrisk forskningssenter, Sykehuset Innlandet, i samarbeid med Nasjonalt kompetansesenter for aldring og helse. Forfatterne er ansatt $i$ hel- eller deltidsstillinger ved disse institusjonene. Alle forfattere er leger, Sverre Bergh er i avslutningen av sin doktorgrad med Knut Engedal, forskningsleder ved Nasjonalt kompetansesenter for aldring og helse og professor i psykogeriatri ved Universitetet i Oslo, og Geir Selbæk, forskningsleder ved Alderspsykiatrisk forskningssenter, som veiledere. Studien omfatter pasienter fra 52 sykehjem ved hjelp av 16 studiesentre. Forskergruppens hovedforskningsområder er demens og nevropsykiatriske symptomer hos hjemmeboende og pasienter på sykehjem.

\section{Erlend Hem}

erlend.hem@medisin.uio.no

Tidsskriftet

\section{Litteratur}

1. Bergh S, Selbæk G, Engedal K. Discontinuation of antidepressants in people with dementia and neu ropsychiatric symptoms (DESEP study): double blind, randomised, parallel group, placebo controlled trial. BMJ 2012; 344: e1566.

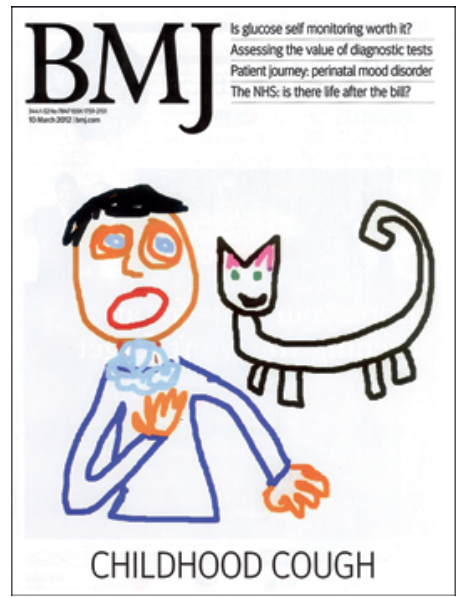

Artikkelen ble e-publisert 9.3. 2012 i BMJ (www.bmj.com), som regnes som en av de «fem store» innen medisinsk publisering, ved siden av New England Journal of Medicine, JAMA, Annals of Internal Medicine og The Lancet. 